\title{
Аномальна маткова кровотеча: сучасний аналіз етіопатогенезу, діагностики та лікування
}

\section{П.О. Ситнік}

Комунальне некомерційне підприємство «Міська клінічна лікарня № 1» Одеської міської ради, Одеса, Україна

Анотація. У статті представлений сучасний аналіз етіопатогенезу аномальної маткової кровотечі, огляд наукових досліджень, що охоплюють симптоматику, методи діагностики та рекомендації щодо вибору тактики і лікування аномальної маткової кровотечі.

Ключові слова: аномальна маткова кровотеча, гістероскопія, гістеректомія, фактори ризику, поліп ендометрія, аденоміоз, лейоміома, гіперплазія ендометрія, коагулопатія, овуляторна дисфункція.

\section{Вступ}

Аномальна маткова кровотеча (АМК) - широкий термін, який описує порушення менструального циклу, включаючи частоту, регулярність, тривалість і обсяг кровотечі поза вагітністю [1, 2]. Поширення АМК досягає 30\% [1]. Середня крововтрата під час нормального менструального циклу становить 30-40 мл, що потребує використання 3-6 прокладок або тампонів на день або 10-15 просочених прокладок або тампонів за цикл [3]. Нормальний менструальний цикл може варіювати в межах 2438 днів, а тривалість менструації 4,5-8 днів з об'ємом крововтрати 5-80 мл за цикл [4, 5].

АМК - найчастіше показання до невідкладної госпіталізації і проведення внутрішньоматкових втручань, може призводити до залізодефіцитної анемії і зниження якості життя жінок $[5,6]$.

у 2011 р. Міжнародна федерація акушерів та гінекологів (International Federation of Gynecology and Obstetrics - FIGO) опублікувала класифікацію PALM-COIEN, яку все частіше використовують у медичній літературі [7]. Відповідно до цієї класифікації виділяють 9 категорій AMK. 4 з них (група PALM) відображають наявність органічних змін і можуть бути діагностовані методами візуальної діагностики та/або морфологічно: поліп $\mathrm{P}$, аденоміоз - A, лейоміома $-\mathrm{L}$, малігнізація або гіперплазія ендометрія - М. Інші можливі причини АМК не пов'язані з органічною патологією і включені до групи COEIN: коагулопатія C, овуляторна дисфункція - O, ендометріальна дисфункція - E, ятрогенні - I та ще не класифіковані - N $[6,8]$. При цьому терміни «дисфункціональна маткова кровотеча» $\mathbf{i}$ «менорагія» слід відкинути $[4,5]$.

\section{Етіопатогенез}

AMK, що пов'язана з поліпом (AMK-P), - найчастіша причина структурних змін, що проявляється тривалою менструацією з подальшим збільшенням обсягу крововтрати [9].

Найбільш частими причинами АМК в пре- і постменопаузальний період - гіперплазія і рак ендометрія, лейоміома, аденоміоз [10]. При пременопаузальній АМК у жінок з цукровим діабетом і ожирінням ризик передракової і злоякісної патології ендометрія підвищується на $25 \%[10,11]$. Однак незалежно від вікової групи, у $2 / 3$ випадків АМК виникає на тлі патології ендота міометрія, серед якої у репродуктивному віці домінують поліп ендометрія і хронічний ендометрит, в період перименопаузи поліп ендометрія і гіперплазія ендометрія [6]. Деякі структурні утворення, такі як поліп цервікального канала, поліп ендометрія або лейоміома, можуть мати безсимптомний перебіг і не бути основною причиною АМК у пацієнтки.

AMK, яка не класифікована, має рідкісну етіологію і включає артеріовенозні мальформації, гіперплазію міометрія, запальні захворювання органів малого таза, хронічні захворювання печінки, цервіцит $[2,3]$. Так, існує зв'язок між хламідійною інфек- цією ендометрія та АМК [8]. Виявлений зв'язок між АМК з можливими вадами рубця після кесаревого розтину [12].

Рясні менструальної кровотечі (РМК) - найчастіший клінічний прояв АМК. Провідною етіологією РМК $\epsilon$ ановуляторні цикли, обумовлені незрілістю осі гіпоталамус - гіпофіз - яєчники і майже у $20 \%$ пацієнток з РМК відмічають супутн $є$ порушення згортання крові [3].

АМК, пов'язана з овуляторною дисфункцією (АМК-О), - найбільш поширена у жінок репродуктивного віку (57,7\%) [1]. АМК-О супроводжується збільшенням обсягу кровотечі або тривалими менструаціями [9]. Крім того, можливими причинами АMК $\epsilon$ ендокринні порушення, такі як гіпотиреоз, гіперпролактинемія і синдром полікістозних яєчників (СПКЯ) [3].

Затримка або відсутність овуляції, СПКЯ, призводить до нестачі прогестерону і надмірного виробництва простагландину $\mathrm{E}_{2} 3$ фолікулів яєчників, викликаючи проліферацію ендометрія і схильність до непередбачуваних менструальних кровотеч [3]. Дефіцит прогестерону і безперешкодна секреція естрогенів призводять до стійкої проліферації ендометрія й індукції виділень, що викликає АМК-О [13].

Для пояснення АМК-О важливе розуміння нормального менструального циклу, який $\epsilon$ результатом гормональних взаємодій в осі гіпоталамус - гіпофіз - яєчники. Передня частка гіпофіза виділяє фолікулостимулюючий гормон (ФСГ) під час фолікулярної фази менструального циклу. Потім ФСГ діє на клітини гранульози, викликаючи вироблення естрогену. Надмірне вироблення естрогену стимулює зростання ендометрія. При цьому зворотні зв'язки ФСГ викликають сплеск лютеїнізуючого гормону, який зумовлює овуляцію. Після овуляції жовте тіло відповідає за вироблення прогестерону, що приводить до секреції ендометрія. Якщо яйцеклітина не запліднюється, має відбуватися синхронне зниження вироблення естрогену і прогестерону в міру дегенерації яйцеклітини і жовтого тіла. Це викликає втрату ендометрія - менструацію. При відсутності овуляції жовте тіло не розвивається, і яєчник не може секретувати прогестерон. Тому у жінок з ановуляторними циклами відмічають тільки естрогенну стимуляцію ендометрія. Це призводить до постійної проліферації ендометрія, що проявляється у вигляді періодичних проривних кровотеч $[1,14]$.

У підлітків часто відмічають нерегулярні та іноді непередбачувані тривалі або надмірні кровотечі, які можуть потребувати невідкладної медичної допомоги. Овуляторна дисфункція $\epsilon$ найчастішою причиною АМК у підлітків $[5,15]$.

У пременопаузальний період менструальні цикли стають коротшими і часто бувають ановуляторними і нерегулярними. Нерегулярний характер кровотечі може посилюватися через «лютеїнові позафазні явища», коли за піком естрадіолу в середині циклу слідує 2-й або навіть 3-й пік. Підвищена частота ановуляторних циклів і подальший вплив естрогену на ендометрій підвищує ризик гіперплазії ендометрія і раку ендометрія у жінок з АМК в перименопаузальний і постменопаузальний періоди [5]. 
Коагулопатії слід розглядати у жінок з рясними і тривалими менструаціями з раннього репродуктивного віку, наявністю в анамнезі частих синців, носових кровотеч, кровотеч з ясен, післяпологових кровотеч і тяжких хірургічних кровотеч. РМК можуть виникати при дефіциті факторів згортання крові (фактори VIII i IX найбільш поширені, фактори VII і XI — рідше) і порушеннях тромбоцитів. Успадковані порушення згортання крові, особливо хворобу фон Віллебранда (vWF), виявляють у 5-24\% жінок з АМК. Антикоагулянти (варфарин, гепарин і пероральні антикоагулянти прямої дії) можуть викликати АМК, тривалу менструацію й АМК в період постменопаузи. Найбільш часті ятрогенні причини АМК пов'язані з гормональною терапією. Так, проривна кровотеча може відмічатися при постійному застосуванні комбінованих оральних контрацептивів (КОК) без прийому інертних таблеток [16].

\section{Діагностика}

Лабораторні дослідження можуть включати аналіз сечі на вагітність, загальний аналіз крові, аналіз на феритин, коагулограму, дослідження функції щитоподібної залози, аналіз на гонадотропіни, пролактин [8]. Після виключення вагітності необхідний детальний анамнез кровотечі й анамнез з акцентом на фактори ризику раку ендометрія, коагулопатії, застосування ліків, супутні захворювання, а також повне фізичне обстеження з урахуванням ознак СПКЯ, інсулінорезистентності, захворювань щитоподібної залози, петехій, синців, захворювань піхви та шийки матки, а також розміру матки [17]. При обстеженні також можна проводити загальний аналіз крові, ультразвукове дослідження (УЗД), гістероскопію і забір ендометрія для біопсії [7]. Методики візуалізації можуть включати трансвагінальне Узд (ТВУЗД), магнітно-резонансну томографію (МРТ), гістероскопію. Хоча ТВУзД не наражає пацієнтку впливом радіації $\mathrm{i} \epsilon$ придатним інструментом скринінгу, проте не $\epsilon$ на $100 \%$ чутливим [8]. Тому гістероскопія і ТВУЗД з внутрішньоматковим контрастуванням (соногістерографія) ефективніші для діагностики поліпів ендометрія у випадках непереконливого зображення ТВУзД. Проте хоча гістероскопія і соногістерографія $\epsilon$ більш інвазивними, їх часто можуть виконувати в амбулаторних умовах [2]. При цьому порівняльне дослідження показало перевагу діагностичної гістероскопії перед ультразвуковими методами щодо чутливості та специфічності при діагностиці АМК: 81 і 65\% відповідно [18].

Коли вагінальний доступ $\epsilon$ неможливим (у підлітків та жінок virgo), ТВУЗД, контрастна соногістерографія й офісна гістероскопія можуть виявитися неможливими. У таких випадках важливу роль відіграє МРТ. Однак в якості альтернативи кращим підходом можуть стати гістероскопічні обстеження з прицільною біопсією, адже будь-яка АМК повинна бути морфологічно позначена $[6,8,19]$. Тільки після виключення злоякісної патології при АМК медикаментозне лікування стає ефективним терапевтичним методом $[15,20]$.

Пайпель-біопсія (ПБ) «працює» так само добре, як дилатація і вишкрібання. Крім того, ПБ $\epsilon$ економічно ефективним методом і краще переноситься з точки зору болю і дискомфорту. Однак іiї використання обмежене стенозом шийки матки, пролапсом тазових органів та атрофією ендометрія. Оскільки ПБ викликає зміни в ендометрії, її не слід проводити перед УзД. Якщо УзД показує локалізовані ураження, проведення біопсії під контролем гістероскопії може виявитися більш корисним, ніж виконання сліпої ПБ [21]. ПБ охоплює тільки 4\% поверхні ендометрія і має чутливість до 97\%. Однак ПБ завжди $\epsilon$ діагностичною процедурою, і негативний результат не виключає ураження ендометрія. При стійких симптомах АМК необхідне дообстеження, що включає проведення гістероскопії для встановлення остаточного діагнозу. Тому найкращі результати свідчать на користь гістероскопічної прицільної біопсії [22, 23].

Офісну гістерсокопію можна використовувати для відбору і лікування простих випадків і сортування складних випадків в амбулаторних умовах. Це дозволить більш ефективно використовувати ресурси вторинної медико-санітарної допомоги [24]. Діагностичну гістероскопію використовують для оцінки харак- теру уражень матки й ендометрія. Пряма візуалізація аномалій дозволяє виконувати спрямовану біопсію залежно від використовуваного обладнання [7].

Тому золотим стандартом діагностики стану порожнини матки та ендометрія вважається морфологічна діагностика з внутрішньоматковими лікувально-діагностичними заходами під візуальним контролем. Таким чином, гістероскопія набуває все більшого значення як метод, що дозволяє виявляти внутрішньоматкову патологію у пацієнток із АМК [18].

\section{Лікування}

Лікування АМК залежить від її етіології, репродуктивних планів жінки, клінічної стабільності пацієнтки та інших супутніх захворювань і має бути індивідуальним з урахуванням цих факторів [2]. Тому лікування АМК повинно бути пов'язане з конкретним захворюванням і спрямоване на усунення основної патології [5]. Лікування АМК може бути медикаментозним та/або хірургічним залежно від причини захворювання. Консервативне лікування АМК, крім лікування залізодефіцитної анемії, можна розділити на негормональну та гормональну терапію. Негормональні методи лікування, що включають антифібринолітики і нестероїдні протизапальні препарати (НПЗП), можуть знизити менструальну крововтрату до 50\% [5, 7]. Транексамова кислота (ТК) - антифібринолітик, який зменшує крововтрату у жінок з АМК. ТК значно знижує активність активатора плазміногену в тканинах ендометрія, рівень інгібітора активатора плазміногену 1-го типу [25]. Відповідно до даних Кокрейнівского дослідження застосування НПЗП при АМК менш ефективне, ніж застосування ТК, даназолу, левоноргестрелвивільняючої внутрішньоматкової системи (ЛНГ-ВМС). Але НПЗП протипоказані жінкам з кровотечами внаслідок порушення функції тромбоцитів $[25,26]$. Дані про ефективність застосування етамзилату при менорагії на сьогодні не знаходять підтвердження. В середньому його ефективність в зниженні менструальної крововтрати не перевищує 13\%, що значно менше, ніж при застосуванні інших лікарських препаратів, зокрема НПЗП [25].

Хірургічне лікування включає видалення осередку ураження, резекцію або деструкцію ендометрія і гістеректомію. Вік, бажання майбутньої вагітності й етіологія АМК $\epsilon$ ключовими факторами, які слід враховувати перед початком лікування [7]. Тільки в ситуаціях гострої і тяжкої кровотечі допустиме лікування з єдиною метою зупинити кровотечу і стабілізувати гемодинаміку пацієнтки, відкладаючи дослідження до того моменту, як кровотеча буде зупинена [17].

Безсимптомні поліпи розміром >1,5 cм і поліпи на тлі АМК повинні бути видалені за допомогою гістероскопії з подальшим гістологічним дослідженням [16], оскільки гістероскопія найточніше дослідження для діагностики поліпів ендометрія. При цьому методика сліпого видалення поліпа з використанням кюреток застаріла і пов'язана з ризиками [27].

Консервативні медичні методи лікування аденоміозу включають гормональне лікування, таке як застосування КОК в безперервному режимі, високі дози прогестинів, селективні модулятори рецепторів естрогену (СМРЕ), селективні модулятори рецепторів прогестерону (СМРП), інгібітори ароматази і тимчасове застосування агоністів гонадотропін-рилізинг-гормону (ГнРГ). Та найбільш перспективною лікарською терапією $\epsilon$ ЛНГ-ВМС з огляду на її ефективність і незначні побічні еффекти. При виконанні абляції ендометрія при аденоміозі частота невдач досягає 20\%. У нерандомізованих дослідженнях емболізація маткових артерій (EMA) і сфокусований ультразвук під контролем МРТ здаються багатообіцяючими методами лікування аденоміозу. Однак при аденоміозі, який часто супроводжується кровотечею і дисменореєю, остаточним методом лікування залишається гістеректомія [16, 17].

Безсимптомні лейоміоми зазвичай не потребують лікування, за винятком випадків, пов'язаних з безпліддям. Коли АМК $\epsilon$ єдиним симптомом, консервативна терапія, яка включає ТК, НПЗП, KOК, даназол, агоністи ГнРГ, інгібітори ароматази, СМРП і СМРЕ, може бути високоефективною [16]. Але терапія довгими циклами 
прогестагенів поступається застосуванню ЛНГ-ВМС і ТК. Оскільки ЛНГ-ВМС діє місцево, то викликає менше побічних ефектів, ніж прогестини, які вводять системно [25]. Також застосування ЛНГ-ВМС ефективне у жінок за наявності захворювань ендо- та міометрія. Але ЛНГ-ВМС може бути технічно складно встановити у жінок з великими лейоміоматозними вузлами, до того ж матка з лейоміомою схильна до підвищеного ризику відторгнення ЛНГ-ВМС [16]. Агоністи ГнРГ викликають аменорею майже у 90\% жінок. Це лікування часто застосовується у жінок з міомою, ефективно зменшуючи розмір міоми і оперативну крововтрату, якщо згодом буде проведена операція. Однак побічні ефекти через гіпоестрогенний стан можуть бути значними. Застосування зазвичай обмежується терміном 6 міс до планової операції. Якщо передбачається більш тривале лікування, може бути призначена замісна гормональна терапія для зменшення вираженості побічних ефектів і захисту від остеопорозу. Систематичний огляд показав, що агоністи ГнРГ, що застосовують за 3-4 міс до операції з приводу міоми матки, зменшують менструальну крововтрату і коригують передопераційну залізодефіцитну анемію. При цьому атрофія ендометрія виникає протягом 3-4 тиж після початку лікування агоністами ГнРГ [25].

СМРП - нова група фармакологічних засобів, що чинять тканиноспецифічну антагоністичну дію по відношенню до прогестерону на ендометрій і міометрій. При правильному дотриманні режиму лікування клінічні випробування продемонстрували контроль АМК у 90\% випадків у жінок з міомою матки. $\epsilon$ переконливі докази того, що ефект СМРП можна порівнювати 3 агоністами ГнРГ для передопераційного лікування міоми матки, що також має кращу переносимість [5].

При підслизовій лейоміомі гістероскопічна міомектомія може бути кращим варіантом лікування АМК. Варіанти зі збереженням матки включають міомектомію, EMA, абляцію фокусованим ультразвуком під контролем МРТ або лапароскопічну радіочастотну абляцію [16]. Гістероскопічна міомектомія з використанням механічних та електрохірургічних інструментів $\epsilon$ безпечним, здійснимим і прийнятним методом як під загальною анестезією, так і в амбулаторних умовах з місцевою анестезією або без неї [27]. Коли АМК викликана інтрамуральною лейоміомою, міомектомія може бути виконана лапароскопічним або лапаротомним доступом залежно від локалізації лейоміоми, доступності матеріалів і підготовки хірурга [17]. Гістеректомія залишається методом лікування симптомів лейоміоми після завершення дітородної функції та коли інші варіанти $\epsilon$ неефективними [16].

Американський коледж акушерів-гінекологів (American College of Obstetricians and Gynecologists - ACOG) рекомендує всім жінкам з АМК віком $>45$ років і жінкам віком $<45$ років 3 додатковими факторами ризику ендометріальної інтраепітеліальної неоплазії (ЕІH) проводити біопсію ендометрія [16]. Тому біопсія ендометрія показана всім жінкам з факторами ризику ЕІH i немає єдиної думки щодо вікової межі для ії проведення. До факторів ризику раку ендометрія відносять ожиріння, цукровий діабет, високий артеріальний тиск, відсутність пологів, сімейний анамнез, синдром Лінча, СПКЯ, а також тривалу АМК і неефективне консервативне лікування. Якщо ж немає підозри на ЕІH, можна запропонувати ПБ. Однак при підозрі на ЕІН прицільна біопсія під час гістероскопії має кращі діагностичні характеристики, натомість сліпа дилатація і вишкрібання мають низьку діагностичну ефективність $[2,7]$.

Офісна біопсія ендометрія $\epsilon$ кращим підходом, оскільки гістероскопію з дилатацією і вишкрібанням треба використовувати у випадках, коли офісна біопсія ендометрія не вдається, неадекватна або неможлива. Але якщо симптоми не зникнуть, незважаючи на нормальні результати біопсії, слід виконувати гістероскопічну дилатацію і кюретаж [28]. Показаннями до проведення біопсії ендометрія або гістероскопії з кюретажем у жінок із АМК при відсутності очевидної внутрішньоматкової патології $\epsilon$ вік $>40$ років, наявність факторів ризику розвитку раку ендометрія, неефективність або протипоказання до проведення медикаментозного лікування $[25,26]$. Так, в постменопаузальний період критеріям норми відповідає те, що товщина ендометрія не по- винна перевищувати 4 мм, в іншому разі пацієнтці показана діагностична гістероскопія або аспіраційна біопсія ендометрія [19].

Ожиріння робить значний внесок у ризик передракових $\mathrm{i}$ злоякісних змін ендометрія, що підвищує ризик неоплазії ендометрія навіть у молодих жінок в 3-му та 4-му десятиліттях життя [8]. > 75\% всього раку ендометрія можна віднести до естрогенасоційованого, та на момент встановлення діагнозу більшість пухлин добре диференційовані й обмежуються маткою. Однак на даний час немає загального профілактичного скринінгу [29], але виявлено, що тільки СА $125 \epsilon$ найкращим маркером для виявлення раку ендометрія з чутливістю $52,63 \%$ і специфічністю 80,00\% [30]. Виходячи з цього, пацієнтці з АМК і порушеннями менструального циклу в анамнезі необхідна біопсія ендометрія незалежно від віку $[8,31]$.

Оптимальним інвазивним втручанням після проведення УзД для AMK категорії COEIN може бути амбулаторна біопсія ендометрія, спрямована на виключення атипової гіперплазії ендометрія і раку ендометрія, які можуть бути причиною АМК у жінок репродуктивного віку. Після верифікації діагнозу призначають відповідні методи медикаментозної терапії [32]. Обстеження при підозрі на коагулопатію має починатися з повного підрахунку клітин крові або кількості тромбоцитів на тромбоцитопенію, дослідження протромбіну (протромбіновий час/міжнародне нормалізоване відношення), активованого часткового тромбопластинового часу, потім, за наявності, дослідження антигену vWF в плазмі крові, активності vWF в плазмі крові, фактора VIII і тестування інших факторів згортання. Успадковані коагулопатії й АМК можна лікувати за допомогою замісної терапії та десмопресину ацетату, а також гормональної терапії. Медикаментозна терапія набутих коагулопатій з АМК може включати внутрішньовенне введення кон'югованих естрогенів по 25 мг кожні 4-6 год протягом 24 год, КОК, що містять 35 мкг етинілестрадіолу, 3 рази на добу протягом 7 днів і потім щодня, або медроксипрогестерону ацетат 20 мг перорально 3 рази на добу протягом 7 днів, потім щодня протягом 3 тиж. Коли медикаментозне лікування коагулопатії не допомагає, після завершення дітородної функції можуть знадобитися абляція ендометрія або гістеректомія [16]. Абляція ендометрія і трансцервікальна резекція ендометрія являють собою неексцизійні методи лікування АМК і $\epsilon$ альтернативою гістеректомії у жінок, які не мають наміру зберегти фертильність. Обидві процедури ефективні та ступінь задоволеності пацієнток $\epsilon$ високим. Та хоча гістеректомія пов'язана з більш тривалим терміном операції, більш тривалим періодом відновлення і більш високим рівнем післяопераційних ускладнень, вона забезпечує постійне полегшення при РМК [4].

КОК ефективні для лікування у 35-69\% випадках і можуть застосовуватися при АМК у пацієнток з овуляторною дисфункцією [28]. Можливими, але рідкісними побічними ефектами КОК, $\epsilon$ хворобливість в ділянці молочних залоз, зміна настрою, головний біль, нудота і блювання. Протипоказаннями до її застосування $\epsilon$ тютюнопаління жінок віком >35 років, артеріальна гіпертензія, серцево-судинні захворювання, мігрень 3 аурою, рак молочної залози, венозна тромбоемболія або тромбогенні мутації. Схеми із застосуванням чистих прогестинів - більш безпечна альтернатива КОК [25]. Однак при безперервному прийомі пероральних прогестинів довгострокова задоволеність пацієнток $\epsilon$ низькою [28]. Внутрішньом'язові ін'єкції медроксипрогестерону зазвичай виконують кожні 12 тиж. Препарат викликає аменорею шляхом пригнічення ФСГ, таким чином, пригнічуючи фолікулогенез і знижуючи синтез і секрецію естрадіолу, що призводить до формування тонкого ендометрія і відсутності менструації. Побічні ефекти медроксипрогестерону включають проривні кровотечі, збільшення маси тіла, себорею шкіри і волосся, акне, здуття живота [25]. $\epsilon$ точка зору щодо доцільності проведення біопсії ендометрія для виключення проліферативних процесів в ендометрії у жінок з хронічною ановуляцією віком <35 років, що мають $\geq 1$ з таких факторів ризику, як цукровий діабет, сімейний анамнез раку кишечнику, безпліддя, відсутність пологів і ожиріння [26].

Лікування АМК 1-ї лінії під час замісної гормональної терапії — індивідуальне гормональне лікування, особливо із засто- 
суванням прогестинів, і хірургічне лікування доцільно тільки у крайньому випадку [33].

Захворювання ендометрія, що обумовлені первинним порушенням функції місцевого гемостазу ендометрія, можна лікувати за допомогою ТК, з огляду на ії антифібринолітичну дію. Також в етіології АМК може відігравати роль запалення ендометрія, або ендометрит, як це буває при інфекціях Chlamydia trachomatis або Ureaplasma. Але інфекція легко піддається лікуванню за допомогою відповідних схем антибіотиків [16].

Гостра АМК визначається як епізод сильної кровотечі, об'єм якої, на думку клініциста, достатній, щоб потребувати негайного втручання для мінімізації або запобігання подальшої крововтрати [8]. Коли крововтрата гостра і значна, а у пацієнтки відмічаються анемія і гіповолемія, 1-м кроком $\epsilon$ відновлення гемодинамічного балансу за допомогою кристалоїдних і колоїдних розчинів. У деяких випадках може знадобитися переливання крові. У той самий час необхідно зупинити кровотечу [17]. Відповідно до даних ACOG гормональна терапія - 1-ша лінія медикаментозної терапії для пацієнток з гострою АМК без порушень згортання крові. Застосування КОК приводить до зменшення обсягу менструальної крововтрати і нормалізації менструального циклу [25]. TК може бути розглянута при гострій АMК із застосуванням у дозі 10 мг/кг маси тіла внутрішньовенно (максимум 600 мг на дозу) або 1,3 г перорально 3 рази на добу протягом 5 днів [16]. Шведське агентство лікарських препаратів (Swedish Medical Products Agency) рекомендує прийом ТК при АМК в дозі 1-1,5 г 3-4 рази на добу перорально протягом 3-4 днів, при цьому доза може бути підвищена до 1 г 6 разів на добу. Європейське агентство з лікарських засобів (European Medicines Agency) peкомендує прийом TК 1 г 3 рази на добу протягом 4 днів та доза може бути підвищена до 4 г на добу. Управління з контролю за харчовими продуктами та лікарськими засобами США (Food and Drug Administration - FDA) рекомендує прийом TK 1,3 г 3 рази на добу протягом 5 днів. Однак тромбоемболія або ниркова недостатність в анамнезі $є$ протипоказаннями до прийому TK [17].

Гемостатичні лікарські препарати дозволяють боротися з крововтратою, що важливо в умовах дефіциту компонентів крові, i викликають економічно обґрунтований позитивний ефект. Але різноманіття місцевих і системних гемостатичних засобів не $\epsilon$ безумовною альтернативою хірургічному гемостазу [34]. Для гемодинамічно нестабільних пацієнток тампонада матки з використанням катетера Фолея 26F з 30 мл фізіологічного розчину може забезпечити швидкий, але тимчасовий контроль крововтрати [16, 28]. При неефективності консервативної терапії необхідно ставити питання про хірургічне лікування [35]. Тому незалежно від клінічних рекомендацій, коли АМК $\epsilon$ стійкою, незрозумілою або гормональне і гемостатичне лікування $\epsilon$ неефективним, необхідно проводити забір ендометрія, при можливості з гістероскопічною оцінкою порожнини матки $[3,8]$. Гістеректомія залишається остаточним і найбільш ефективним лікуванням АМК, яке забезпечує високий рівень задоволеності пацієнток [28].

\section{Висновки}

1. Будь-яка АМК повинна бути морфологічно позначена.

2. Тільки після виключення злоякісної патології при АМК медикаментозне лікування стає ефективним терапевтичним методом.

3. Лікування АМK залежить її етіології, репродуктивних планів жінки, клінічної стабільності пацієнтки та інших супутніх медичних захворювань та має бути пов'язане з конкретним захворюванням і спрямоване на усунення основної патології.

4. Золотим стандартом діагностики стану порожнини матки та ендометрія вважається морфологічна діагностика з внутрішньоматковими лікувально-діагностичними заходами під візуальним контролем.

5. СА $125 \epsilon$ найкращим маркером для виявлення раку ендометрія з чутливістю $52,63 \%$ та специфічністю $80,00 \%$.

6. При неефективності консервативної терапії необхідно ставити питання про хірургічне лікування.

7. Гістеректомія - остаточне і найбільш ефективне лікування при АМК.
Список використаної літератури/References:

1. Sun Y., Wang Y., Mao L. et al. (2018) Prevalence of abnormal uterine bleeding according to new International Federation of Gynecology and Obstetrics classification in Chinese women of reproductive age: a cross-sectional study. Medicine, 97(31): e11457. doi:10.1097/ MD.0000000000011457.

2. Davis E, Sparzak P.B. (2021) Abnormal Uterine Bleeding. In: StatPearls. Treasure Island (FL): StatPearls Publishing, 30422508. https://www.ncbi.nlm.nih.gov/pubmed/30422508

3. Elmaoğulları S., Aycan Z. (2018) Abnormal Uterine Bleeding in Adolescents. J. Clin. Res. Pediatr. Endocrinol., 10(3): 191-197. doi:10.4274/jcrpe.0014.

4. Chodankar R., Critchley H.0. (2019) Abnormal uterine bleeding (including PALM COEIN classification). Obstet. Gynaecol. Reproduct. Med., 29(4):98-104. doi:10.1016/j.ogrm.2019.01.009

5. Cheong Y., Cameron I.T., Critchley H.0. (2017) Abnormal uterine bleeding. Br. Med. Bull., 123(1): 103-114. doi:10.1093/bmb/ldx027.

6. Chernukha G.E., Ivanov I.A., Efendieva Z.N. et al. (2018) Etiological structure and diagnostic possibilities of abnormal uterine bleeding. Gynecology, 20(2). doi:10.26442/20795696_2018.2.14-18 (In Rus.).

7. Levy-Zauberman Y., Pourcelot A.G., Capmas P., Fernandez H. (2017) Update on the management of abnormal uterine bleeding. J. Gynecol. Obstet. Human Reproducti., 46(8): 613-622. doi:10.1016/j.jogoh.2017.07.005.

8. Munro M.G., Critchley H.O., Fraser I.S. (2018) The two FIGO systems for normal and abnormal uterine bleeding symptoms and classification of causes of abnormal uterine bleeding in the reproductive years: 2018 revisions. Int. J. Gynecol. Obstet., 143: 393-408. doi:10.1002/ ijgo.12666.

9. Sun Y., Wang Y., Mao L. et al. (2018) Prevalence of abnormal uterine bleeding according to new International Federation of Gynecology and Obstetrics classification in Chinese women of reproductive age: a cross-sectional study. Medicine, 97(31). doi:10.1097/ MD.0000000000011457.

10. Chechulina O.V., Kurmanbaev T.E., Tukhvatullina L.M. et al. (2019) Disorders of the hemostatic system as the main pathogenetic mechanism in the occurrence of abnormal uterine bleeding in the postmenopausal period. Kazan Med. J., 100(4). doi: 10.17816/ KMJ2019-589 (In Rus.).

11. Giannella L., Cerami L.B., Setti T. et al. (2019) Prediction of endometrial hyperplasia and cancer among premenopausal women with abnormal uterine bleeding. BioMed Res. Int., Article ID 8598152. doi:10.1155/2019/8598152.

12. Chen Y.Y., Tsai C.C., Kung F.T. et al. (2019) Association between hysteroscopic findings of previous cesarean delivery scar defects and abnormal uterine bleeding. Taiwanese J. Obstetr. Gynecol., 58(4): 541-544. doi:10.1016/j.jog.2019.05.020.

13. Wang L., Guan H.Y., Xia H.X. et al. (2020) Dydrogesterone treatment for menstrual-cycle regularization in abnormal uterine bleeding-ovulation dysfunction patients. World J. Clin. Cases, 8(15): 3259. doi:10.12998/wjcc.v8.i15.3259.

14. Jewson M., Purohit P., Lumsden M.A. (2020) Progesterone and abnormal uterine bleeding/ menstrual disorders. Best Pract. Res. Clin. Obstetr. Gynaecol. doi:10.1016/j.bpobgyn.2020.05.004.

15. Singh S., Best C., Dunn S. et al. (2018) Abnormal uterine bleeding in pre-menopausal women. J. Obstetr. Gynaecol. Canada, 40(5): e391-e415. doi:10.1016/j.jogc.2018.03.007.

16. Marnach M.L., Laughlin-Tommaso S.K. (2019) Evaluation and management of abnormal uterine bleeding. Mayo Clin. Proceed., 94(2): 326-335. doi:10.1016/j.mayocp.2018.12.012.

17. Benetti-Pinto C.L., Rosa-e-Silva A.C.J.D.S., Yela D.A., Soares Júnior J.M. (2017) Abnormal uterine bleeding. Revista Brasileira de Ginecologia e Obstetrícia, 39(7): 358-368. doi:10.1055/s-0037-1603807.

18. Alieva D.A., Askarova Z.Z., Karimova G.S. (2020) The value of hysteroscopy in the diagnosis of abnormal uterine bleeding in perimenopause. Sci. Ed. Is., 37 (121). (In Rus.).

19. Ashrafyan L.A., Antonova I.B., Ivashina S.V. et al. (2019) Optimization of diagnostic tactics in patients with abnormal uterine bleeding during peri- and postmenopausal periods. Obstetrics and gynecology: opinion news, training, 7(1):24-30. doi:10.24411/2303-9698-2019-11003. (In Rus.).

20. Singh P. (2018) Abnormal Uterine Bleeding — evaluation by Endometrial Aspiration. J. Midlife Health, 9(1):32-35. doi:10.4103/jmh.JMH_109_17.

21. Narice B.F., Delaney B. Dickson J.M. (2018) Endometrial sampling in low-risk patients with abnormal uterine bleeding: a systematic review and meta-synthesis. BMC Fam. Pract .,19: 135. doi:10.1186/s12875-018-0817-3.

22. Pennant M.E., Mehta R., Moody P. et al. (2017) Premenopausal abnormal uterine bleeding and risk of endometrial cancer. BJOG,124: 404- 411. doi:10.1111/1471-0528.14385.

23. Ilavarasi C.R., Jyothi G.S., Alva N.K. (2019) Study of the efficacy of pipelle biopsy technique to diagnose endometrial diseases in abnormal uterine bleeding. J. Mid-life health, 10(2): 75 . doi:10.4103/jmh.JMH_109_18.

24. Kolhe S. (2018) Management of abnormal uterine bleeding — focus on ambulatory hysteroscopy. Int. J. Women's health, 10: 127. doi:10.2147/JWH.S98579. 
25. Dobrokhotova Yu.E., Saprykina L.V., Filatova L.A., Narimanova M.R. (2020) Abnormal uterine bleeding: management algorithms, therapy methods. RMJ. Mother and child, 3(1). doi:10.32364/2618-8430-2020-3-1-55-60 (In Rus.).

26. Chernukha G.E., Ilyina L.M., Ivanov I.A. (2018) Abnormal uterine bleeding: diagnosis and treatment. Gynecology, 20(4). doi:10.26442/2079-5696_2018.4.4-8 (In Rus.).

27. Clark T.J., Stevenson H. (2017) Endometrial Polyps and Abnormal Uterine Bleeding (AUB-P): What is the relationship, how are they diagnosed and how are they treated? Best Pract. Res. Clin. Obstetr. Gynaecol., 40: 89-104. doi:10.1016/j.bpobgyn.2016.09.005.

28. Wouk N., Helton M. (2019) Abnormal uterine bleeding in premenopausal women. Am. Fam. Phys., 99(7): 435-443. https://www.aafp.org/afp/2019/0401/p435.html.

29. Ouassou K., Klingelhöfer D., Brüggmann D. (2020) Endometriumkarzinom. Zentralblatt für Arbeitsmedizin, Arbeitsschutz und Ergonomie, 1-5. doi:10.1007/s40664-020-00395-6

30. Kumar N.U., Sridhar M.G., Srilatha K., Habebullah S. (2018) CA 125 is a better marker to differentiate endometrial cancer and abnormal uterine bleeding. Afr. Health Sci., 18(4): 972-978. doi:10.4314/ahs.v18i4.17.

31. Ash S.J., Farrell S.A., Flowerdew G. (1996) Endometrial biopsy in DUB. J. Reprod. Med., 41: 892-896. https://europepmc.org/article/med/8979202.

32. Pestrikova T.Yu., Yurasova E.A., Yurasov I.V., Sukhonosova Ye.L. (2017) Possibilities of drug therapy with a combined oral contraceptive containing estradiol valerate and dienogest for heavy uterine bleeding (literature review). Reproduction problems, 23(6): 34-38. doi:10.17116/repro201723634-38 (In Rus.).

33. Römer T. (2017) Blutungsstörungen unter menopausaler Hormontherapie. Gynäkologe, 50: 599-605. doi:10.1007/s00129-017-4103-6.

\section{Відомості про автора:}

Ситнік Павло Олексійович — кандидат медичних наук, лікар акушер-гінеколог, комунальне некомерційне підприємство «Міська клінічна лікарня № 1» Одеської міської ради, Одеса, Україна. ORCID ID: 0000-0001-7542-0964

\section{Адреса для кореспонденції:}

Ситнік Павло Олексійович

65005, Одеса, вул. Степова, 32, кв. 21

E-mail:pasha_si@ukr.net
34. Rukhlyada N.N., Krylov K.Yu., Biryukova E.I., Novikov E.I. (2017) Pharmacological treatments for abnormal uterine bleeding. Medical alphabet, 1(5):45-48. https://www.med-alphabet. com/jour/article/view/63 (In Rus.).

35. Bedei I., Delisle B. (2017) Zyklusstörungen in der Adoleszenz. Monatsschrift Kinderheilkunde, 165(10): 858-865. doi:10.1007/s00112-017-0376-z.

\section{Abnormal uterine bleeding: modern analysis of etiopathogenesis, diagnosis and treatment}

\section{P.O. Sytnik}

Municipal non-profit enterprise «City clinical hospital № 1» of the Odessa City Council, Odessa, Ukraine

Abstract. The article presents a modern analysis of the etiopathogenesis of abnormal uterine bleeding, a review of scientific studies covering the symptoms, methods of diagnosis and recommendations for the choice of tactics and treatment of abnormal uterine bleeding.

Key words: abnormal uterine bleeding, hysteroscopy, hysterectomy, risk factors, endometrial polyp, adenomyosis, leiomyoma, endometrial hyperplasia, coagulopathy, ovulatory dysfunction.

\section{Information about the author:}

Sytnik Pavlo 0. - Candidate of Medical Sciences, obstetrician-gynecologist, Municipal nonprofit enterprise «City clinical hospital № 1» of the Odessa City Council, Odessa, Ukraine. ORCID ID: 0000-0001-7542-0964

\section{Address for correspondence:}

Pavlo Sytnik

65005, 0dessa, Stepova str., 32, ap. 21

E-mail:pasha_si@ukr.net 